\title{
Tourism and Forestry Collaboration in Bali-Indonesia
}

\author{
I Gusti Bagus Rai Utama
}

Management Study Program, Economics and Humanities Department

Dhyana Pura University, Bali, Indonesia

Corresponding author: raiutama@undhirabali.ac.id

\begin{abstract}
ARTICLE INFO
ABSTRACT

Received

20 February 2015

Accepted

05 August 2015

Available online

07 September 2015

The declining interest of the younger generation in forestry education has become a global issue while forestry continues to play an immense role for human lives throughout the world. This decline should be anticipated by higher education institutions by forming a collaboration between forestry education and another, more appealing, and education program. For Bali, which has relied on the tourism sector as the main driver of its local economy, collaboration between the tourism sector and forestry sector seems natural. Based on case studies in Bali,the idea of utilizing forest areas for tourism have entered a new phase that is as one of the drivers for foreign domestic tourists to travel to Bali. Several forest areas that have been for tourism include the mangrove forests of Badung regency, Tabanan's botanical gardens, and West Bali National Park in Jembrana and Buleleng regencies. Collaboration between forestry and tourism is aimed at attracting tourists, absorbing more labor force, and preserving natural resources.
\end{abstract}

Keywords: participation, ecological tourism, "manuk jegeg"

\section{Introduction}

The numbers of student are interested in the pursuing forestry education has declined dramatically and the decrease of required skills for professional foresters have caused uncertainty among forestry educators. Over the past 10 years, forestry education in Indonesia has continued to decline on an annual basis and significant changes have occurred (Sasmita, 2015). The downward trend of interest in forestry education is not an isolated experience in Indonesia alone. The trend is also seen in several European and American countries, which is the declining number of individuals who want to pursue post-secondary study for a degree in forestry. The decrease is estimated up to $30 \%$ overall (Temu, Mwanje and Mogotsi, 2003). This problem is recognized as a global crisis facing professional forestry education (Miller, 2004).The similar trend happened in the UK,

http://ojs.unud.ac.id/index.php/eot in which a dramatic decrease occurred in the sheer number of higher education institutions offering forestry programs, from about 325 in 1996 to only 156 programs in 2003 (Burley et al., 2005). Likewise in Canada, the trend has shown similar decrease, where the number of students enrolled in forestry programs decreased from 1,881 in 1996 to 1,463 in 2004 (Innes and Ward, 2010).

Table 1. Higher Education Institutions in Indonesia

\begin{tabular}{lr}
\hline Type of Institution & Number \\
\hline Academy & 1,095 \\
Polytechnic & 226 \\
College & 2,323 \\
Institute & 118 \\
University & 508 \\
Total & 4,270 \\
Institutions offering Forestry & 47 \\
\hline Proportion & $1.1 \%$ \\
Source: DIKTI (2015)
\end{tabular}

Source: DIKTI (2015)

e-ISSN: 2407-392X. p-ISSN: 2541-0857 
Today there are 54 forestry study programs in Indonesia, spread among threeyear diploma, 4-year bachelor, master, and doctorate degree programs offered by 47 or a mere $0.3 \%$ of public and private postsecondary education institutions (see appendix) of the 4,270 higher education institutions operating in Indonesia today (see Table 1).

The proportion and sheer number of postsecondary education institutions offering forestry education in Indonesia illustrate that the forestry sector is considered less important and less appealing to the nation's younger generation. Interest of the younger generation of forestry education program at only $4.7 \%$ is sufficient to indicate that the program is less attractive to younger generation as a program that can promise a better future (see Table 2).

Tabel 2. Study Programs in Post-Secondary Education Institutions in Indonesia

\begin{tabular}{lrr}
\hline $\begin{array}{l}\text { Type of Study } \\
\text { Program }\end{array}$ & $\begin{array}{r}\text { Number of } \\
\text { Study Program }\end{array}$ & $\begin{array}{r}\text { Number } \\
\text { of } \\
\text { Students }\end{array}$ \\
\hline Religious Studies & 682 & - \\
Humanities & 619 & 118,037 \\
Social Studies & 3,284 & 745,634 \\
Math and Science & 777 & 141,697 \\
Art & 312 & 44,894 \\
Health & 2,956 & 633,650 \\
Engineering & 4,108 & 935,742 \\
Agriculture (included & 1,490 & 242,069 \\
Forestry) & 2,882 & 968,821 \\
Economics & 4,312 & $1,298,243$ \\
Education & 21,422 & $5,128,787$ \\
Total & 54 & 242,069 \\
Forestry & $0.3 \%$ & $4.7 \%$ \\
\hline Proportion & & \\
\hline Solnre & $51 K$ & \\
\hline
\end{tabular}

Source: DIKTI (2015)

\section{Collaboration with Tourism}

The reason the declined interest in forestry education is very complex. Here are two compelling factors: First, would-be students do not know and understand about forestry. Forestry is not commonly taught at the secondary school level, even many students do not realize the existence of forestry discipline. The premise that forestry education program is not very market-oriented (Temu, Mwanje and
Mogotsi, 2003). Luckert (2006) also stated that the decrease relates to reduced employment opportunities for graduates of professional forestry. Currently, there are only four study programs in Indonesia that respond to the interest of the downward interest of the younger generation on forestry. These study programs are collaborations between the forestry and tourism. The programs are offered to the public as ecotourism education programs (See Table 3).

Table 3

Post-Secondary Institutions Collaborating Forestry with Tourism

\begin{tabular}{|c|c|c|c|}
\hline No. & Level & Institution & Study Program \\
\hline 1 & D-III & $\begin{array}{l}\text { Institut Pertanian } \\
\text { Bogor (Bogor } \\
\text { Agricultural } \\
\text { University) }\end{array}$ & Ecotourism \\
\hline 2 & D-III & $\begin{array}{l}\text { Politeknik Negeri } \\
\text { Manado (Manado } \\
\text { State Polytechnic) }\end{array}$ & $\begin{array}{l}\text { Underwater } \\
\text { (marine) } \\
\text { Ecotourism }\end{array}$ \\
\hline 3 & $\mathrm{~S} 2$ & $\begin{array}{l}\text { Institut Pertanian } \\
\text { Bogor (Bogor } \\
\text { Agricultural } \\
\text { University) }\end{array}$ & $\begin{array}{l}\text { Ecotourism } \\
\text { Management and } \\
\text { Environmental } \\
\text { Services }\end{array}$ \\
\hline 4 & $\mathrm{~S} 3$ & $\begin{array}{l}\text { Institut Pertanian } \\
\text { Bogor (Bogor } \\
\text { Agricultural } \\
\text { University) }\end{array}$ & $\begin{array}{l}\text { Ecotourism } \\
\text { Management and } \\
\text { Environmental } \\
\text { Services }\end{array}$ \\
\hline
\end{tabular}

Temu, Mwanje and Mogotsi (2003) identified a number of cases in which forestry education programs need to be changed to be back in demand. Several recommendations include: (1) Restructuring forestry education to address cross-sectorial issues and other issues such as food security and poverty. (2) Including the subjects of park management and low-laying forest management into the discipline of forestry education. (3) Starting a global mechanism to stimulate investment in forestry education, particularly educator training, curriculum assessment and pedagogical development that is relevant to the current issues. (4) Developing strategies that help make forestry education relevant to young people and women, well-integrated into programs that reflect forestry in the broader sense. (5) Strength in human resource capacity of in the area of tree management outside of the forest areas. (6) Increase collaboration between forestry and other institutions, including but not limited tothe tourism industry and the emerging industry of herbal medicine. 


\section{Eco-Tourism for Increasing the Interest of Forestry Education in Indonesia}

One form of forestry diversification as well as tourism diversification is the development of ecotourism. Gregorius (2005) explained that, aside being known for its rich culture and natural scenery, Bali also has a number of artificial tourism attractions in the form of parks. Parks are synonymous with flowers, trees and various animal species, thus giving birth to the image of beauty, nature and freshness. On holidays, visitors swarm the gardens to learn about the collections or simply to eliminate boredom and to escape daily routines. To be able to preserve its beauty, parks and gardens need substantial amounts of funds. The existing gardens in Bali today have largely been well-maintained, either by the government or the private sector or by the cooperation of both. Managers are required to have many ways and means for fundraising to finance the parks' maintenance. Without management, the collection of the parks will be stagnant, not well maintained and eventually abandoned by visitors (Gregorius, 2005).

Other than as a place of recreation, parks also have the function of education and conservation. Bali Botanic Garden is not referred to as a park, but it can be categorized as a park when seen from its function. The park hosts various species of trees, from common to rare. Bali Botanic Garden, in fact, has applied the concept of ecotourism in its management because the park nurtures and cultivates various types of plants such as orchids and other tropical flowers to be sold as recreational services products and for tours (Gregorius, 2005).

The presence of parks is believed to strengthen Bali's appeal as a tourism destination. However, more artificial objects are needed to enrich Bali's tourism appeal and to empower communities as far as economic growth. If Bali only survives with its existing

http://ojs.unud.ac.id/index.php/eot traditional attractions, there is a possibility that Bali will be abandoned by tourists or at least will lose its appeal. More statistical data about visitors to the parks is needed to support this assertion (Gregorius, 2005).

Bali Botanic Garden was originally created as a plant conservation institution, but has since developed into a charming and attractive tourist attraction (i.e., recreational park), because it combines elements of natural beauty, rarity, and diversity of plant species. By doing research on visitors to the Bali Botanic Garden, it is expected that useful information can be gathered for the development of parks or other botanical gardens in Bali. Bali Botanic Garden is one of four botanical gardens under the management of the Indonesian Institute of Sciences (LIPI). The master plan for the development of Bali Botanic Garden is based on the analysis of long-term needs as follows: (1) collecting various types of Gymnospermae, i.e. types coniferous plants from all over the world, (2) collecting plant species from all over Bali and Nusa Tenggara whose natural habitat is derived from mountain or highland wetlands, (3) providing recreational and tourism object in Bali, in addition to providing facilities for scientific knowledge, (4) undertaking additional efforts to support the financing of the botanic gardens (Sujana, 2002).

Among the richness of plant collections in Indonesia's four botanical gardens in Indonesia, Bali Botanic Garden is recorded to have 20 plant types, while Purwodadi Botanic Garden has 48 plant species, Cibodas Botanic Garden has 55 types of plants, and the garden with the highest number of collection is Bogor Botanic Garden with 177 plant types. Meanwhile, the primary tasks of Bali Botanic Garden are performing inventory, exploration, and conservation of tropical plants from the highland wetlands with high scientific and educational value. To carry out these tasks, Bali Botanic Garden has the following functions: (1) to perform an inventory of the 
various types of tropical plants from the highland wetlands, (2) to perform exploration of tropical plant species whose habitat is the moist highlands, (3) to perform conservation of tropical plants from the moist highlands that have the potential scientific and economic value in order to preserve biological diversity (germ plasm) of Indonesian, (4) to conduct scientific services in the field of landscape architecture in the form of gardening a variety of ornamental plants (floracultural), the introduction and encourage community appreciation on the efficacy of natural plants, and (5) to perform administrative activities (Sujana, 2002).

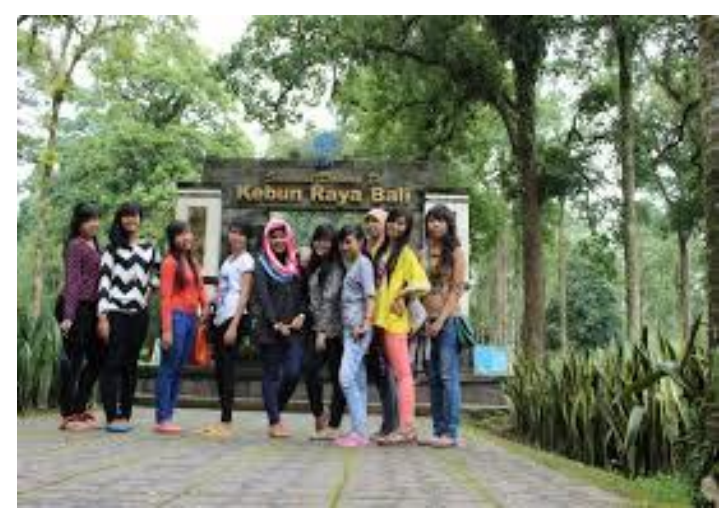

Picture 1. Outing Activity in Bali Botanic Garden

Source: www.anythingbali.com (2015)

Picture 1 shows the Bali Botanic Garden as a beautiful, charming, and well-kept attraction still appealing to many tourists. Well-kept rare trees with a variety of wellpreserved plants indicate that managers of Bali Botanic Garden are still consistent with their assigned tasks. Increasing the interest of forestry educationcan be seen from the findings are summed up as follows:

The characteristics of respondents who visited Bali Botanic Garden can be described as follows: (a) the respondents or visitors of Bali Botanic Garden were dominated by domestic visitors; (b) students and private employees were the dominant groups of visitors when it came to profession of respondents; (c) the respondents also were dominated by the age group of 20 to 40 years old; (d) the respondents were dominated by those who are repeat visitors to Bali Botanic Garden; (e) there were more men than women respondents or tourists who visited Bali Botanic Garden. Foreign respondents generally had a positive perception of Bali Botanic Garden as a part of the eco-forestry object by placing the available attractions at Bali Botanic Garden at the first rank, then the accessibility and facilities as the second rank, and the attributes of Bali Botanic Garden as the third rank when it came to the appealing features of the botanical garden. Domestic respondents also had a positive perception of Bali Botanic Garden, placing attraction first, facility second, and accessibility third as the appealing features of Bali Botanic Garden. Domestic and foreign respondents had the same perception of Bali Botanic Garden, which is predominantly positive especialy as eco-tourism object.

To maintain the eco-tourism for increasing the interest of forestry education in Indonesia are needed five factors in conjunction with tourist visits. These factors are: (a) fees and services (variance explained 27.791\%), (b) natural attractions (explained variance $15.712 \%$ ), (c) accessibility (explained variance $12.010 \%$ ), (d) atmosphere (explained variance $7.990 \%$ ), and (e) facility (explained variance $5.715 \%$ ). The research findings and discussion of this study indicated that natural beauty is the main attraction for Bali Botanic Garden, which has been able to provide considerable stimulus for young generations to visit Bali Botanic Garden as the new image of the forestry sector. Indeed, there are several recommendations proposed to the managers of Bali Botanic Garden, visitors and government officials as follows:

Managers should diversify the product offerings based on a priority scale, the first priority being fees and services, the second priority should be the natural attractions, third

e-ISSN: 2407-392X. p-ISSN: 2541-0857 
the accessibility, the fourth priority should be the atmosphere, and the fifth factor is the facilities. The first consideration should be given to the domestic market segment, the younger age group (20-40 years), and maintaining good relationship with existing and repeat visitors. Because more than $75 \%$ of respondents visiting Bali Botanic Garden did so for recreational purposes, then the creation and distribution of brochures and other forms of dissemination of information should emphasize the recreational nature of this botanical garden with the hope of adding new nuances and marketing added value for tourists, in addition to keeping the main task of this botanical garden as forestry institution for plant conservation.

The sustainability, beauty, and diversity of plant species in Bali Botanic Garden will be preserved if visiting tourists participate in the efforts to create sustainability. Tourist visits is expected to continue, since visits to this park allow managers attain funding for maintenance, planting new plants, garden arrangements, as well as other economically and socially beneficial efforts. Government officials, managers, and the general public should cooperate in all respects, especially in terms of economic benefits by applying the concept of income distribution to avoid unwanted conflicts. Stakeholders of Bali Botanic Garden can give guidance to the communities around the park in terms of sale of plants, provision of souvenirs, sale of vegetables, and sale of fruits so that the local people can feel the benefits of the existence of Bali Botanic Garden. Business practitioners interested in developing a park or botanical garden should take advantage of these study findings, that fees and services have the greatest influence in attracting visitors, then natural attractions including the collection of flowers, trees, and orchids supported by natural beauty also have great influence in appealing to visitors. Other factors including facilities, atmosphere, and accessibility should also be considered in the development of agrobased recreational park.

\section{Conclusion and Recommendation}

In essence, every ecosystem with all its contents (physical and biological resources) is a tourism attraction that can be further developed as natural attractions. In such condition, the utilization of forests as a tourism attraction can provide opportunities to promote forestry education as an attractive program for modern societies and for the younger generation to work as a forestry expert as well as ecotourism guides.

To make forestry education programs interesting for young people, collaboration and cooperation between forestry and other sectors, such as tourism, is essential. Forestry education and forestry-related training programs can be carried out based on the type and level of education and training desired by skilled forestry educators and trainers that may include: training for guides, teacher, lecturer, managers of education programs and training units, technical personnel and other educational personnel.

One form of forest management can be in the right to manage. Forest management rights are intended to support research and development activities, education and training programs by research institutes, education and community development by both public and private sectors, in realizing sustainable forest management for the greatest prosperity of the people.

\section{References}

Burley, J., Plenderleith, K., Howe, R. and Freer-Smith, P. (2005) 'Forest education and research in the United Kingdom', Forest Science and Technology. Taylor \& Francis, 1(2), pp. 67-76.

Gregorius (2005) Perkaya Khazanah Wisata. Available at: http://www.balipost.co.id/balipostceta k/2005/5/19/pa2.htm. 
Innes, J. L. and Ward, D. (2010) 'Professional education in forestry', Commonwealth forests.

Luckert, M. K. M. (2006) 'Has the myth of the omnipotent forester become the reality of the impotent forester?', Journal of Forestry. Society of American Foresters, 104(6), pp. 299-306.

Miller, H. (2004) 'Trends in forestry education in Great Britain and Germany, 1992 to 2001', UNASYLVA-FAO-. UN FOOD AND AGRICULTURE ORGANIZATION, pp. 29-32.

Sasmita, N. (2015) 'Peran Pendidikan Kehutanan di Indonesia Menghadapi Asean Single Communnity 2015'.

Sujana, I. W. (2002) 'Perumusan Strategi Pengelolaan Objek Wisata Kebun Raya Eka Karya Bali di Candikuning Baturiti Tabanan'. Master Thesis). Universitas Udayana. Denpasar.

Temu, A. B., Mwanje, J. I. and Mogotsi, K. K. (2003) Improving Agriculture and Natural Resources Education in Africa: A Stitch in Time--. World Agroforestry Centre. 